\title{
The Relationship between Training and Employee Performance: The Case of Mutare City Council, Zimbabwe
}

\author{
Wehnam Peter Dabale (Corresponding Author) \\ Alumni Affairs Directorate \\ Africa University \\ P. O Box 1320 Mutare \\ Zimbabwe \\ Email: dabalew@africau.edu \\ Prof Nelson Jagero (PhD) \\ Faculty of Human Development and Education \\ Chuka University \\ P.O BOX 109 Chuka Kenya \\ Email: jageronelson@yahoo.com
}

\author{
Mentline Nyauchi \\ Faculty of Management and Administration \\ Africa University \\ P. O Box 1320 Mutare \\ Zimbabwe \\ Email: mentlinenyauchi@yahoo.com
}

Doi:10.5296/ijhrs.v4i4.6620

URL: http://dx.doi.org/10.5296/ijhrs.v4i4.6620

\begin{abstract}
The Success of failure of an organization depends on the quality of its human resources and training being an integral part of the strategy to integrate human resources management with an organizations business strategy, coming at the age where employees are beginning to realize that employers have the potential to be much more dynamic and beneficial to the organization. Hence, this study was aimed to determine the relationship between training and employee performance in Mutare City Council, Zimbabwe. Correlational research design was used in this study, with an attempt describe and measure the degree of association between performance and training. A total of one hundred and thirty two (132) respondents
\end{abstract}


(91 males and 41 females) were selected from the employees (population), purposive sampling technique and structured questionnaire were used in data collection. Data was analyzed using quantitative techniques, including inferential statistics. It was established that there was strong positive relationship between training and performance of employees. It was recommended that all stakeholders, be involved in one way or the other in training to enhance employee knowledge, skills, ability, competencies and behaviour.

Keywords: Relationship, Training, Employee, Performance and City Council

\subsection{INTRODUCTION}

Success or failure of an organization generally depends on the quality of its human resources and the human resource has played a significant role in the economic development in most developed countries such as Japan, Britain and United States of America. In a country like Zimbabwe the same can be done, if the appropriate attention is given to the development and training of human resources (Bernstein, 2008).

Training is designed to provide learners with the knowledge and skills need for there their present job (Fitzgerald, 1992) since the formal educational system does not adequately teach specific job skills for a position in a particular organisation. Few employees have the requisite skills, knowledge, abilities and competencies needed to work. As a result, this many require extensive training to acquire the necessary skills to be able to make substantive contribution towards the organisation growth (Arsmtrong, 2001).

The factors that may influence the quantity and quality of training activities according to Cole (2002) included, the degree of change in the external environment, the degree of internal change, the availability of suitable skills within the existing workforce and the extent to which managers see training as a motivating factor in work; these makes many organisations meet their needs for training haphazardly, more or less planned and unsystematic.

This study was carried out at the Mutare city council in Zimbabwe; the city council has more than one thousand two hundred employees. It was to determine the relationship between training and performance of these employees.

\subsection{Statement of Problem}

The success or failure of an organisation depends on the quality of human resources (Shora, 2004). The training of workers is an integral part of the strategy to integrate human resources management with an organisation's business strategy. In Zimbabwean, the city councils see training as an important issue in local government; it was also argued that, the majority of municipal workers need new or significantly expanded skills to keep up with the demands of their jobs.

However, the Mutare City council seems not to be performing well as seen on their budget 
deficits reports, misappropriation of funds, long queues experienced by rate payers wishing to pay for rates and licences and its failure to provide the needed funds to maintain, repair and improve roads, sewage systems, swimming pools, crèches and council buildings among many other problems.

Consequently, as asserted by Mathis and Jackson (2009), that performance is associated with quantity of output, quality of output, timeless of output, presence or attendance on the completed and effectiveness of work completed; therefore, this study was to determine the relationship between training and employee performance in a city council with particular reference to Mutare City council in Zimbabwe.

\subsection{LITERATURE REVIEW}

\subsection{Training of City Councils Employees}

Training is the organised procedure by which people learn knowledge or skills for a definite purpose (Jones and George, 2005). The objective of training is to achieve a change in the behaviour of those trained. This means that the trainees shall acquire new manipulative skills, technical knowledge and skills on the job in such a way as to aid in the achievement of organisational goals (Archieve, 2008).

Grobler et al (2006) described training as the use of specific means to inculcate specific learning, using techniques that can be identified and described. These techniques and methods should be continually improved. Training therefore is a deliberate effort to teach specific skills, knowledge and attitudes to serve a specific purpose (Archive, 2008). Training is not only aimed at improving the employee`s knowledge and skills with regard to his or her functional and administrative duties, but the acquisition of certain virtues and attitudes like diligence, willingness, integrity, loyalty and responsibility is also within its scope.

At any organisational level, training is very important to meet corporate goals. This includes city councils were training is identified continually in order to achieve organisational goals. In line with the above, (Lane and Robinson, 2009) are of the opinions that training impart positively, effectively for optimum performance to archive corporate goals of the organisation. Training allows city councils employees, such as those of Mutare City Treasurer`s Department to have a better job understanding and quality of work of city council employee (Omole, 2005).

In practice the nature, content and extent of training received by personnel should be reconciled with the needs of the organization for staff trained in particular fields. Training needs to be given under the guidance of a knowledgeable instructor. It is necessary that, person responsible for the training of a particular employee or group of employees should have the necessary knowledge, skills and attitudes to do a meaningful job (Stahl, 2009).

In Europe council departments have the responsibility to identify training needs, based on 
available resources and staff; to prepare and conduct training programs that will effectively meet those needs which are unique to the operations of the department concerned (Dowling et al, 2008). These sentiments were concurred by Collis and Hussey (2009) that personnel are surely the most important component in any public institution. Training ensures that individuals are more productive as they acquire the necessary skills. Training from the time of employment is considered to be a necessary and continuous personnel function. In Asia, city councils encourage employee training opportunities for all its employees to insure that services they provide to the community are made more effective (Chevalier, 2007).

In Nigeria the importance of training is more obvious given the growing complexity of the work environment, the rapid change in organisations and advancement technology, among other things (Stahl, 2009). City councils have come to recognize that training offers a way of developing skills, enhancing productivity and quality of work and building the loyalty to the firm. Jones and George (2005) concurred that training in city councils help improve quality, customer satisfaction, productivity, morale, management succession and business development.

Zimbabwe being a developing country, there are development in a variety of community areas, such as technology, sociology, politics and economics. This results in arrangements having to be made to make available sufficient, trained personnel in all public institutions so as to satisfy the increasing demand (Shora, 2004). Zimbabwe is in a transformation process and we live in an ever faster changing world, technological changes, the changing constitutional and political dispensation of Zimbabwe certain amendments and changes have to be made by organisations such as municipalities, to empower their people and meet future expectations.

The municipalities are composed of people coming from different backgrounds they need to be trained to fill the gaps arising from these cultural backgrounds. Collis and Hussey (2009) mentioned that, training programs are formal efforts to help employees learn new skills, improve existing skills and to perform in the organization. Training is needed in part because people, jobs and organisations are always changing. Further training can help ease management resistance to change. In addition, training should begin when individuals joining the firm and should continue throughout careers.

\subsection{Performance of Employees of City Councils}

Becker et al, (2011) stated that employee's performance is measured against the performance standards set by the organization. Good performance means how well employees performed on the assigned tasks. In every organization there are some expectations from the employees with respect to their performance. When they perform up to the set standards and meet organizational expectations they are believed good performers.

Every organization has been established with certain objectives to achieve. These objectives 
can be achieved by utilizing the resources like men, machines, materials and money. All these resources are important but out of these, manpower is the most important. It plays an important role in performing tasks for accomplishing the goals. The question then arises that, how these resources are utilized by manpower. Furthermore, the business environment is changing drastically. The environment factors are uncontrollable (Bright, 2008). These are beyond control of most municipalities, for such as the City of Mutare. One has to adjust with the external factors to achieve organizational goals. Every environmental factor like social, cultural, legal, political, economic, technology and competition gets changed very fast. For effective working the knowledge of these factors is must, otherwise the plan will misfire. The need for highly skilled and dedicated manpower is felt, who can give the best output. For every organization, it is difficult to survive, stabilize and excel without the talented and dedicated manpower. The performance of employees on different jobs in close coordination is needed for the success of the unit (Bruce, 2003).

Various factors like skills, training, motivation, dedication, welfare, management policies, fringe benefits, salary and packages, promotion and communication are responsible to encourage the people to work sincerely and give their best output. The importance of council employee's performance must be understood by the management and sincere efforts must be put in that direction (Collis and Hussey, 2009).

In Europe, good performance of city employees is enhanced using a triangulation frame work which is a framework of analysis that provides for a perspective on how to better understand the dynamics of local service delivery systems and the requirements of improving them, with a view to replicating best practices and learning dysfunctional ones. Jones et al (2005), say it is a triangulation because local service delivery is better understood and improved if it is viewed from three angles or components, that is good policy environment and effectiveness, accountable institutional actors and efficient intergovernmental fiscal and financial systems.

In Asia for instance in Brisbane City Council, which is the largest local government in the Asia - Pacific region, encourage employees to contribute to a high performing team culture. This includes the ability to give and receive feedback so as to develop as professionals and improve individual team performance (Bruce, 2003) while in Africa performance of city council employees in treasurers department is maintained by placing strategies in improving local service delivery. These strategies address key issues and challenges of the department (Omole, 2008).Employees are involved in the planning process which will help them understand departmental goals, what needs to be done, why it needs to be done and how it should be done to improve individual performance.

Performance can be influenced by the mission of the organisation, the objectives it is pursuing, and the physical, social and economic environment in which the organisation is operating. This could be true for Mutare City Council. The organisation has been operating in a hyper inflationary environment and in unstable political environment which saw mayors and councillors being removed from offices. This may have had impacted negatively on the 
efficiency and effectiveness of the organization. (Safferstone, 2007) However higher performance of city council employees involves the employees playing the following roles as stipulated by Grobler et al (2006). Planning, meeting and discussing with their managers and supervisors in the beginning, regarding accountability, performance standards and behaviour and, give suggestions for better performance to the managers.

\subsection{Relationship between Training and Performance City of City Councils}

Nickels, (2009) says the effects of training on employee`s performance can often encourage growth within the worker and the organisation itself. Training of city council employees leads to self fulfilling prophecy of enhanced output by employers, employee development equals decrease in operational costs, leads to greater loyalty to the organisation and as well enhanced job satisfaction. He further says that the effects of training on employee performance include meeting and exceeding expectations, cross training of staff, preparing employees for promotion, maintaining a safe environment and reduction of errors.

Training generates benefits for the employee knowledge, skills, ability , competencies and behaviour (Benedicta, 2010). It is obvious that training plays an import role in the development of organization, improving performance as well as increasing productivity, and eventually putting companies in the best position to face competition and stay at the top. This means that, there is a significant difference between the organizations that train their employees and those organisations that do not (Becker et al, 2011).

Therefore, organisations that are dedicated to generating profits for its owners (Shareholders) and providing quality service for its customers and beneficiaries usually invest in the training of its employees (Dowling et al, 2008). Most organisations have long recognized the importance of training to its development. As new technologies progress, making certain jobs and skills redundant, an increasing emphasis is being placed on the need for a skilled and highly trained workforce for good performance. Many of the jobs being replaced by machines have been of an unskilled nature, and this emphasizes the need for a higher education and skills for those wishing to gain employment in the future. (Armstrong, 2001)

In Europe city council performance is enhanced by giving the training needed to the employees to produce desired outcomes. Managers understand that most employees do not come to their jobs with the total knowledge and experience required for them to perform perfectly (Archieve 2008). Hence a manager is needed to select appropriate training options so that they may advance to a desired level of performance while in the United States of America, relationship between training and employee performance is done by giving council employees two kinds of training to improve their performance (Stahl, 2009). First the city councils give general training to give employees new knowledge and skills, which will be transferable to any future job. Second, the city council offer training in skill specific to its 
technologies and work processes. Focusing on council specific training is important because the councils derives its competitive advantage from what its employees know and can do, that cannot be found elsewhere (Jones et al, 2005).

In South Africa training and performance of city councils is enhanced by fully engaging their employees in required training gaps and cultivate exceptional work environments (Safferstone, 2007). City council managers encourage training and each individual to meet performance goals. After meeting their goals employees update their goals and write new goals to continue moving ahead in their performance, with the help of their supervisor's

Management of employs on matters concerning performance can result in highly complex and emotion- filled decisions. Motivation of the employee is an important factor that may ensure that the employees remain focused on the organization's goals and objectives. This includes work based and external training. (Grobler et al 2006). Training involves enabling people to perform their work to the bet of their ability, meeting and perhaps exceeding $g$ targets and standards.

Employees that are trained by their organisations are more involved to the assigned tasks. (Becker et al 2011). The employees who are very committed to the job assignments are an essential part of their live. After their better performance, they feel satisfaction, this nature of job involvement deemed towards self esteem. (Bright, 2008). After being trained personnel become highly motivated for doing innovative tasks when they feel high involvement in their jobs (Chevalier, 2007).

Training improves employee performance in the human resource as well as the organisation. If employees are whole heartedly involved in training issues which are directly related to their job, then they try to take initiatives to remove many problems (Safferstone, 2007). Involvement in the official tasks directly influences the employee performance. Effort is an intervening relationship of training and performance. Training is therefore a key element to city councils performance. It helps to reconcile the gap between what should happen and what is happening between desired targets or standards and actual levels of work performance (Armstrong, 2001). Training need is any shortfall in employee performance, or potential performance which can be remediated by appropriate training. There are many way of overcoming deficiencies in human performance at work, and training is the only one of them.

The City Treasurer's Department of Mutare City Council does not seem to take training as a priority; hence the advantages listed above are not enjoyed by its employees. The result is high employee turnover, low morale, and low sense of motivational variables of recognition, achievement, growth and responsibility. This has impacted negatively on the development of the City of Mutare. 


\subsection{Theoretical Framework}

\subsubsection{Maslow's Motivation Theory}

Abraham Maslow (1908-1970) propounded the Maslow`s Motivation Theory in 1943; he proposed five levels of needs as indicated by Cheminias et al (2000) to include self-actualization, esteem needs, social needs, safety needs and physiological needs. Maslow (1943) argued that some people appear to be content with lower level needs, but only until these are satisfied, they would then strive for the next level.

The Maslow Motivation theory is related to the study as working can be seen as a tool that employees can use to satisfy his or her needs. Conversely, employees can use motivation as a useful tool to heighten employee performance (Armstrong and Murlis, 2004). A person`s job has a bearing on the choices he or she will have to make regarding, social status, suburb he or she will live in, schools that his or her children will attend, friends he or she will associate with and self - development and learning options.

Performance according to Amos et al (2004) can only be enhanced with increased motivation and morale; thus desire has to be accommodated and facilitated and employee performance is the product of ability multiplied motivation. However, Grobler et al (2006) opined that employee performance is ultimately an individual phenomenon with environmental factors influencing performance primarily through their effect on the individual determinants of performance - ability and motivation. Highly motivated employees created a positive attitude towards learning and development. Armstrong (2001) concurred with Grobler et al (2006) that high commitment means employees will be motivated to hear, understand and respond to management's communication relating to the organisation of work.

Therefore, Maslow`s Motivation Theory is important as it assist the learner acquire the behaviour necessary for effective performance. People learn if they accept the need for training and commit to it. If their motivation is weak, for instance if they doubt their ability to learn, no matter how well their training is designed and implemented, its effectiveness will be limited (Bruce, 2003). As supported by Armstrong (2001) that the more highly motivated the trainee, the more quickly and thoroughly a new skill or knowledge is learned. This means training should be based on what the employee desires, such as job promotion and recognition to enhance performance. Maslow`s model has had a considerable impact on the study of motivation in general and in particular with regards to employee performance that relates to this research.

\subsection{RESEARCH METHODOLOGY}

\subsection{Research Design}

According to Babbie and Mouton (2001), a design serves as the blue print that indicates how the investigation is expected to be carried out. Correlational research design was used in this study with an attempt describe and measure the degree of association (or relationship) between 
the dependent variable (performance) $\mathrm{X}_{2}$ and the independent variable (training) $\mathrm{X}_{1}$ according to the following equation:

$\mathrm{X}_{2}=\mathrm{a}+\mathrm{b} \mathrm{X}_{1}$

Where $\mathrm{X}_{2}=$ Performance

$\mathrm{X}_{1}=$ Training

$\mathrm{a}=$ Constant

\subsection{Data Analysis}

SPSS statistics which is a windows based program that can be used to perform data entry, analysis and to create tables and graphs (sweet and Martin, 2011) was used to analyzed the data. The use of descriptive statistics, which is a set of brief descriptive coefficients that summarizes a given data set, which can either, be a representation of the entire population or a sample (Babbie, 2009).

The measures used to describe the data set are measures of central tendency and measures of variability or dispersion. Measures of central tendency included the mean, median, and mode, while a measure of variability includes the standard deviation (or variance), the minimum and maximum variables, kurtosis and skewness (Nick and Todd, 2007) and data were presented in forms of tables.

Inferential statistics used were Pearson Correlation, Analysis of Variance (ANOVA) and Simple regression. The advantage of using these inferential statistics is that they permit the researchers to analyze relationships among a number of variables in a single study (Gall and Borg, 1996).

\subsection{Findings and Discussions}

\subsection{Inferential Statistics}

Table 1: Model Summary

\begin{tabular}{ccccc}
\hline Model & $\mathbf{R}$ & $\mathbf{R}^{\mathbf{2}}$ & Adjusted $\mathbf{R}^{\mathbf{2}}$ & Standard Error \\
\hline 1 & $.587^{\mathrm{a}}$ & .344 & .339 & .967 \\
\hline
\end{tabular}

Predictors: Training $\mathrm{X}_{1}$

Dependant Variable: Performance $\mathrm{X}_{2}$

In table 1, the multiple $\mathrm{R}$ is a correlation between the dependent variable (performance) and the independent variable (training). It can be seen from the table that the correlation between the dependent variable and the independent variable was as low as 0.587 . The multiple $R$ square $\left(\mathrm{R}^{2}\right)$ is the proportion of variance in the dependent variable associated with variance in the dependent variables. This proportion is a good indicator of the explanatory power of the regression model. 
Therefore, from the table $1, \mathrm{R}^{2}$ is 0.344 . This shows that the dependent variable $\mathrm{X}_{2}$ (performance), according to the model summary is $34.4 \%$ affected by the independent variable $\mathrm{X}_{1}$ (training). The other $65.6 \%$ of the factors absent from the model summary could have been from the participant's different characteristic such as incentives, good working environment and opportunities for growth.

Table 2: Regression Coefficient

\begin{tabular}{cccccc}
\hline Model & $\begin{array}{c}\text { Unstandardized } \\
\text { Coefficient Beta }\end{array}$ & $\begin{array}{c}\text { Standard } \\
\text { Error }\end{array}$ & $\begin{array}{c}\text { Standardized } \\
\text { Coefficient Beta }\end{array}$ & t & Sig \\
\hline Constant $(\mathrm{a})$ & 0.456 & 0.163 & - & 2.804 & 0.006 \\
Training $\left(\mathrm{X}_{1}\right)$ & 0.816 & 0.099 & 0.587 & 8.263 & 0.000 \\
\hline
\end{tabular}

Predictors: Training $\mathrm{X}_{1}$

Dependant Variable: Performance $\mathrm{X}_{2}$

The model from the table 2 can be expressed as follows:

$\mathrm{X}_{2}($ Performance $)=0.456+0.816 \mathrm{X}_{1}$

The beta column indicates the value of standardized regression coefficient. Beta represents the effect that standard deviation difference in the independent variable would have on the dependent variable in standard deviation (the standardized scores of the dependent variable).

Therefore from the regression analysis the unstandardized beta when $\mathrm{X}_{1}$ (training) was regressed against $\mathrm{X}_{2}$ (performance) was 0.587 with $\mathrm{t}$ value of 8.263 which was far greater than 2.00 and a significance of $0.000(<0.005)$. This shows that $X_{1}$ is a major predicator of $X_{2}$. This could be interpreted that a $10 \%$ increase in training at Mutare city council will increase the performance of its employees by $4.56 \%$.

\subsection{Discussion of Findings}

It was established from this study that there is a positive relationship between training and performance. Training generates benefits for the employee knowledge, skills, ability, competences and behaviour (Benedicta, 2010). From the findings most respondents strongly agreed that training develops skills and competences to improve performance, it reduces learning time for employees starting new jobs on appointment, transfer or promotion and training helps to reconcile the gap between what should happen and what is happening to increase the level of performance.

Moreover as Nickels (2009), opined the effects of training on employee`s performance can often encourage growth within the worker and the organisation itself. Most respondents agreed that, training plays an important role in the development of organisations, improving performance and training helps people to grow within the organisation in order to meet the future needs for employees. 


\subsection{Conclusion and Recommendation}

The study affirmed that there was a positive relationship between training and employee performance. Training generates benefits for the employee knowledge, skills, ability, competencies and behaviour. It was also observed that training alters behaviour of employees in a direction that will achieve organisational goals and help to reconcile the gap between what should happen and what is happening to increase the level of performance.

It is therefore strongly recommended that all stakeholders, the mayor, directors, senior managers, junior managers, supervisors and the employees should be involved in one way or the other in training as there is a positive relationship of training and performance to enhance employee knowledge, skills, ability, competencies and behaviour. This could also be done through support and involvement. 
Archieve, B. (2008). Effect of Training and Manpower Development on Productivity of Workers, New York, Harper and Row Publishers

Armstrong, M. J. (2001). A Handbook of Personal Management Practice, London

Amos, T. L, Ristow, A. and Ristow L. (2004). Human Resource Management. 2nd Ed. Lansdowne: Juta and Co Ltd.

Benedicta, A. A. (2010).The Impact of Training on Employee Performance (Ghana Ltd)

Bernstein, D. A. (2008). Essentials of Psychology. $5^{\text {th }}$ Edition. Belmont, CA, USA: Wadsworth Cengage Learning

Becker, K., Antuar, N., and Everett, C. (2011). Implementing an Employee Performance Management System in a Nonprofits Organization. Nonprofits Management and Leadership. 21(3), 255-271

Chevailier, R. (2007). A Manager's Guide to Improving Workplace Performance. New York: American Management Association

Collis, J. and Hussey, R. (2009). Business Research: A Practical Guide for Undergraduate and Postgraduate Students. $3^{\text {rd }}$ Edition. Hampshire, U.K: Palgrave Macmillan

Dowling, P.J, Festing, M. and Engle A. D. (2008). International Human Resources Management: Managing in a Multinational Context. London. Thompson Learning

Grobler, P., Warnich, S., Carrell, M. R., Elbert, N. F. and Hatfield, R. D. (2006). Human Resource Management in South Africa. 3rd edition. London: Thompson Learning.

Jones, G. R., and George, J. M. (2005). Contemporary Management, New York, Irwin and McGraw Hills

Omole, M. A. L. (2004). Training and Re-Training: A Variable of Technological Development. Journal of Industrial Education, 14 (2), 76-85

Safferstone, M. J. (2007). Organizational Leadership: Classic Works and Contemporary Perspectives. Academic Leadership the Online Journal, 5(1), Spring 2007

Stahl, O. G. (2009). Public Personnel Administration, New York, Harper and Row Publishers

Shora, R. M. (2004). Training and Development, Harare, Z.O.U. 